\title{
The adoption of market-based practices within care for older people: is the work satisfaction of Nordic care workers at risk?
}

\section{Teppo Kröger}

Department of Social Sciences and Philosophy

University of Jyväskylä

Email: teppo.kroger@jyu.fi

\begin{abstract}
Market-based practices, including privatization and the increased emphasis on managerialism, have entered Nordic social- and health-care systems for older people. This article examines whether the adoption of these practices has affected the work satisfaction of care workers in Denmark, Finland, Norway, and Sweden. The data used comes from a postal survey conducted in spring 2005 among Nordic care workers, covering 2716 respondents who provided care for older people. The items analysed include background questions, Likert-scale questions on working conditions, and questions on the presence of different market-based practices in the workplace. The results indicate that there are many variations between the four Nordic countries concerning the adoption of market-inspired practices in the care for older people, with Denmark having been the most eager and Norway the least to introduce them. Employees of for-profit employers report a lower level of work satisfaction than public employees. On the other hand, the adoption of most market-based instruments correlates with higher and not lower levels of work satisfaction among care workers working with older people. The results do not show a simple connection between the adoption of market-based practices and lower levels of work satisfaction, which might have been expected on the basis of earlier research discussions. However, due to some weaknesses of the data and the many variations between individual market-based models as well as between different Nordic countries, there is cause for caution in the interpretation of the results. It is particularly necessary for policymakers to remain sensitive to the national context.
\end{abstract}

Keywords: Care work, older people, work satisfaction, Nordic countries, New Public Management, privatization, market-based practices 


\section{Introduction}

Social- and health-care service systems of Nordic countries are well known as the most universal and publicly organized of their kind. While in many other countries, for-profit and non-profit organizations play a central role in the provision of social- and health-care services, in the Nordic region their role has been limited. It has instead been the public authorities at the central, regional, and particularly at the local levels that have assumed the overwhelming responsibility for providing the services and for employing care workers. The existence of publicly offered care services that are broad in coverage has led some researchers to call these services 'the key to the Nordic welfare model' or to conceptualize Nordic welfare states as 'social-service states', in contrast to, for example, Central European 'social-insurance states' that offer their citizens social-security cash benefits but not public-care services on a grand scale (Anttonen, 1990; Sipilä, 1997).

However, the Nordic region is not immune to international trends affecting the organization of public services everywhere. Models and doctrines that emphasize managerialism, cost-efficiency, and accountability have also spread to the social-democratic welfare regime, guiding the reforms of public administration since the late 1980s. Known as New Public Management (NPM), this trend has brought attributes of a new character, such as totalquality management, balanced scorecards, management by results, and costcontrol mechanisms. These have appeared within Nordic public services and also in the care services for older people (Doyle \& Timonen, 2007, 21-38; Hasselbladh et al., 2008; Højlund, 2001; Julkunen, 2004; Vabø, 2003). It has been said that Nordic care systems have seen 'a cultural change where the rationality of efficiency has become a salient logic in formerly socially defined care' (Wrede et al., 2008, 28).

In addition to the advancement of NPM, another influential international market-inspired tendency that has gained increasing strength since the 1980s has been the privatization of the provision of care services, following the example of Thatcher's and Blair's Britain (see e.g., Means et al., 2002; Wistow et al., 1994, 1996). The trend to outsource service provisions to for-profit providers reached the Nordic region in the 1990s (Behning, 2005; Lund Pedersen, 1998; Vabø, 2003). Since then, a growing number of Nordic municipalities have created quasi-markets of care and turned the primary role of local authorities from 'in-house provision' into purchasing services from a number of different providers. According to Means et al. (2002, 135), 'quasimarkets are based on a belief in the cost effectiveness of getting a number of providers to compete for business from a single purchaser, namely the social services department'. Such a belief has become increasingly common within the Nordic countries.

Furthermore, new models that promote 'consumer choice' have been spreading in Nordic care service systems for older people (Edebalk \& Svensson, 2005; Söderström, 2001). As another way to promote privatization, users of publicly organized and funded care services are more and more often given the option to choose between a public provider and one or more private providers. Also, the traditional in-house provision is still available if the user prefers it, but by offering for-profit and non-profit alternatives, authorities encourage privatization of at least some parts of public-care service provisions. In Finland, this consumer choice is primarily promoted through a new voucher system, formulated in a piece of special legislation in 2004, while in Denmark local authorities have in the case of home-based services been 
required from 2003 to offer users a choice between a private and a public service (Edebalk \& Svensson, 2005, 36-41; Doyle \& Timonen, 2007, 23; Kröger, 2009, 112-115).

All in all, market-based models are no longer foreign to the Nordic countries in the field of care services for older people. Here, both an increased focus on managerial control and efficiency as well as outright privatization of service provisions are counted as market-based practices. They arrived in the region more than a decade ago and their influence is becoming increasingly tangible. However, the five nations of the region are not identical in this regard, as the national governments in Denmark, Finland, Iceland, Norway, and Sweden have taken up market-inspired ideas and practices at different paces (Wrede et al., 2008, 26-27). Furthermore, as Nordic municipalities are largely autonomous in their making and implementation of care policies (see Kröger, 2011; Karlson et al., 2010; Lund Pedersen, 1998; Martimo, 1998), the advancement of market-based principles and practices has been asynchronous and patchy. Within-country variations are wide and complex, though often the trend has been fastest in major cities and considerably slower in the rural areas (e.g., Vabø, 2003).

Many Nordic care researchers have been very critical of the adoption of market-inspired models (e.g., Dahl, 2005; Koskiaho, 2008; Vabø, 2003). These have been said to challenge the Nordic welfare model that is based on universalism and public provision, and it has been argued that NPM represents an ideology that is opposite to the rationality of caring. Wrede et al. (2008) go so far as to state that the recent focus on efficiency and managerialism has caused a crisis in care work in the Nordic countries, bringing recruitment problems as well as medicalization and Taylorization of care work.

Does this mean that the work satisfaction of care workers who provide services to older people is also at risk? Does the adoption of market-based practices reduce the satisfaction of Nordic care workers with their work and working conditions? From earlier research it is known that work satisfaction is a critical factor for the recruitment and retention of staff, as well as for the quality of care for older people (see Trydegård, 2005), but has this satisfaction been affected by the emerging privatization and the advancement of managerialism in the Nordic countries?

Despite the lively debate concerning the adoption of market-based models, empirical studies - in particular comparative Nordic ones - on the conditions of care work remain rare. The research question of this paper is to ask whether there are differences in the level of work satisfaction between those Nordic care workers caring for older people who have experienced the adoption of market-based models in their workplaces, and those care workers who have not yet had such a personal experience. The question of whether the adoption of market-based practices is connected with the level of work satisfaction will be analysed here through comparisons between four Nordic countries, and also through comparisons between different market-inspired models.

\section{Data and methods}

The data used comes from a postal survey that was conducted in spring 2005 among care workers in Denmark, Finland, Norway, and Sweden (Iceland being the only Nordic country that was not involved). The 12-page 
questionnaire was designed jointly by a Nordic research team that included researchers from all the four countries, and was led by Marta Szebehely from the University of Stockholm (see Kröger et al., 2009). It was pilot tested and further developed in each of the four countries. The study (titled NORDCARE) was directed at basic-level care workers (nurses excluded) who during the previous 12 months had worked with older or disabled people within social- or health-care services, and who were employed by either public, for-profit or non-profit organizations. The questionnaire was posted to 1200 random sampled members of the main labour unions of care workers in each country (in Denmark: FOA; in Finland: JHL, Super and They; in Norway: Fagforbundet; in Sweden: Kommunal). ${ }^{1}$ The great majority of care workers in all Nordic countries are organized in labour unions - for example more than 80 per cent of home-care workers are unionized in Denmark (Doyle \& Timonen, 2007, 33) - so the respondents represented the majority of Nordic care workers within social and health-care services. The number of responses was 3208 in total, with national response rates varying from 66.6 per cent in Sweden to 79.9 per cent in Denmark. For the analysis of this paper, only those respondents who were working with older people were included, which reduced the number of responses to 2716 .

Although care work has been studied eagerly within the Nordic countries for decades, this questionnaire study was the first Nordic project that gathered original data from different countries, aiming through its design and sampling methods for the best possible comparability. The questionnaire covered a large number of issues because the aim of the project was to gain comparative knowledge on the general state of care work in the Nordic region. In addition to background variables such as age, gender, employer, training for care work, and work settings, two specific sets of questions provided the most essential data for this paper.

The first of these two sets was focused on work satisfaction. Work satisfaction has been the focus of intensive research for decades, which has also generated many theories on its causes and implications (see e.g., Locke, 1976; Rode, 2004; Weiss, 2002). In brief, work satisfaction describes how satisfied a person is with his or her work. There are many ways to measure it, among which Likert scales are the most commonly used. Research on work satisfaction has also been active concerning care work (see e.g., Hannan et al., 2001; Häggström et al., 2005; Redfern et al., 2002). On the based of instruments used generally in work-satisfaction research, the Nordic research team of the NORDCARE project included ten items of work satisfaction in the questionnaire with which respondents were asked to evaluate different issues of their work and working conditions using a four-point Likert scale. ${ }^{2}$

\footnotetext{
${ }^{1}$ In Norway this sample was later supplemented with 150 additional people because in the original sample, care workers working in home-based care were found to be underrepresented.

${ }^{2}$ These questions were:

'a. Do you find your tasks interesting and meaningful?

b. Have you got too much to do in your job?

c. Does your work present the opportunity to learn new things and to develop professionally?

d. Can you affect the daily planning of your work?

e. Does your boss provide you with sufficient information regarding changes in your workplace?

f. Have you got enough time to discuss difficulties in your work with your colleagues?

g. Do you get support in your work from your line manager?

h. Are you provided with the training necessary for your work?

i. Do you ever feel inadequate because the care recipients are not receiving the help you think is necessary?
} 
The other section of the questionnaire that is vital for this paper comprised questions concerning the care workers' experience of the occurrence of different market-based practices. These questions covered the separation of needs-assessments from provision and asked about the existence of qualitycontrol systems, local for-profit providers, customer choice, and competitive tendering. ${ }^{3}$ The development of quality-assurance systems offers managers a new instrument to document and monitor efficiency continuously and to standardize and formalize service provisions (Højlund, 2001; Szebehely, 2001) while the existence of for-profit providers is clearly a condition for the privatization of public-care provisions. The separation of needs-assessments from provision makes outsourcing possible. Customer choice and competitive tendering, for their part, are instruments of the privatization of care services.

The article analyses variations between the four Nordic countries as well as between different market-based practices by using cross-tabulations, measuring statistical significance with $x^{2}$ and $p$-values. In addition, Pearson's correlations are used in order to grasp the connections between the adoption of different market-based models and the work satisfaction of care workers.

The article describes first the basic characteristics of the respondents, presenting the similarities and dissimilarities between the four Nordic countries. After that, the occurrences of different market-based models and care workers' evaluations on their work conditions are reported, with a focus on whether there are differences in self-reported work satisfaction between employees of public and non-public employers. Finally, there is an analysis and presentation of the associations between, on the one hand, privatization and the adoption of market-inspired mechanisms and, on the other hand, the work satisfaction of care workers in the four countries. The article concludes with a discussion on the findings and possible implications for policy.

\footnotetext{
j. Do you worry about possible changes in your work situation due to reorganization, completely new work methods or the like?'

For each question, the same four response alternatives were given: 'most often', 'sometimes', 'only rarely', and 'never'.

${ }^{3}$ These questions were preceded by an introduction:

'Recently, quite a few municipalities have reorganized the care for older and disabled persons. Some have initiated a purchaser-provider model where a special needsassessment officer decides the amount and form of help provided for a person and orders the assistance from a municipal or private provider unit. Some municipalities have initiated customer-choice models, where the care user chooses the provider she/he would like to be assisted by. Here are some questions regarding the organization at your workplace.'

The questions were:

'a. Is there a certain needs-assessment officer (situated outside your workplace) who decides the assistance provided for the care recipients?

b. Are there any private for-profit providers of care and services for older and disabled persons in the municipality where you work?

c. Has your workplace been exposed to competitive tendering (meaning that different private and public providers have competed for a contract)?

d. If they want to, is it possible for care users to switch to another provider unit without extra cost (the so-called customer-choice or voucher system)?

e. Is your workplace regularly measured by quality standards and/or compared to other workplaces in the local care sector?'

For each question, the same three response alternatives were given: 'yes', 'no', and 'I don't know'.
} 


\section{Results}

\section{The profile of Nordic care workers working with older people}

To put it briefly, in all four Nordic countries care workers who provide care for older people are, in general, middle-aged women who are born in their country of residence, who have training in and extensive experience of care work, who are employed by the public sector, and who work primarily in residential settings (table 1). A more detailed look shows the variations between Denmark, Finland, Norway, and Sweden to be statistically significant. For example, according to the data, Sweden has clearly the youngest staff ( 33.7 per cent being under 40 ) and Norway the oldest (44.5 per cent being 50 or over). Sweden is also the country that has the largest share of men (4.0 per cent) and migrants (12.9 per cent) working in care for older people.

Table 1. Background data on Nordic care workers working with older people by country $\left(\% ; \chi^{2}\right)$

\begin{tabular}{|c|c|c|c|c|c|c|}
\hline Variables & $\begin{array}{l}\text { All participants } \\
\quad(n=2716)\end{array}$ & $\begin{array}{c}\text { Denmark } \\
(n=790)\end{array}$ & $\begin{array}{l}\text { Finland } \\
(n=654)\end{array}$ & $\begin{array}{l}\text { Norway } \\
(n=716)\end{array}$ & $\begin{array}{l}\text { Sweden } \\
(n=556)\end{array}$ & $\chi^{2}$ \\
\hline \multicolumn{7}{|l|}{ Age } \\
\hline Under 40 years & 28.3 & 26.5 & 29.5 & 25.1 & 33.7 & \multirow{3}{*}{$16.6^{*}$} \\
\hline $40-49$ years & 30.4 & 33.2 & 28.6 & 30.5 & 28.6 & \\
\hline 50 years or over & 41.3 & 40.4 & 41.9 & 44.5 & 37.7 & \\
\hline \multicolumn{7}{|l|}{ Gender } \\
\hline Woman & 97.7 & 98.3 & 98.8 & 97.3 & 96.0 & \multirow[t]{2}{*}{$12.2^{* *}$} \\
\hline Man & 2.3 & 1.7 & 1.2 & 2.7 & 4.0 & \\
\hline \multicolumn{7}{|l|}{ Birth place } \\
\hline Country of residence & 94.7 & 95.8 & 99.1 & 95.3 & 87.1 & \multirow[t]{2}{*}{$90.0^{* \star *}$} \\
\hline Abroad & 5.3 & 4.2 & 0.9 & 4.7 & 12.9 & \\
\hline \multicolumn{7}{|l|}{ Care work training } \\
\hline Under 1 year & 20.1 & 16.4 & 12.8 & 25.2 & 27.6 & \multirow{3}{*}{$117.2^{* * *}$} \\
\hline $1-2$ years & 43.7 & 53.8 & 37.9 & 39.6 & 41.6 & \\
\hline 2 years or over & 36.1 & 29.8 & 49.3 & 35.2 & 30.8 & \\
\hline \multicolumn{7}{|l|}{ Care work experience } \\
\hline Under 10 years & 30.8 & 32.7 & 33.1 & 24.1 & 33.9 & \multirow{3}{*}{$22.4^{* *}$} \\
\hline $10-19$ years & 33.0 & 30.7 & 32.2 & 36.4 & 33.0 & \\
\hline 20 years or over & 36.2 & 36.5 & 34.8 & 39.6 & 33.0 & \\
\hline \multicolumn{7}{|l|}{ Work settings } \\
\hline Home-based settings & 22.6 & 28.0 & 19.0 & 16.3 & 27.3 & \multirow{4}{*}{$83.1^{\star \star \star}$} \\
\hline Residential settings & 60.9 & 52.7 & 69.4 & 63.6 & 59.3 & \\
\hline Both settings & 12.4 & 14.2 & 7.1 & 16.8 & 10.6 & \\
\hline Other settings & 4.0 & 5.1 & 4.5 & 3.3 & 2.8 & \\
\hline \multicolumn{7}{|l|}{ Employer } \\
\hline Public & 94.4 & 97.0 & 86.1 & 98.6 & 95.2 & \multirow{4}{*}{$149.9^{* \star \star}$} \\
\hline Non-profit & 2.3 & 1.6 & 7.0 & 0.7 & 0.0 & \\
\hline For-profit & 2.5 & 0.5 & 5.2 & 0.6 & 4.4 & \\
\hline Other & 0.8 & 0.9 & 1.7 & 0.1 & 0.4 & \\
\hline
\end{tabular}

Source: NORDCARE data

" $p<0.05 ; " p<0.01 ; " p<0.001$ 
On the other hand, Finnish care workers have backgrounds of longer professional training (49.3 per cent having had training of at least two years) than their Nordic colleagues, and working in residential settings (including different forms of sheltered housing, in addition to traditional institutional care) is also most common in Finland (69.4 per cent). The largest variations between the four countries concern employers of care workers. Whereas, according to the data, non-public employers in care for older people are still very rare in Norway and Denmark, they are more common in other countries, particularly in Finland, which has the highest proportions of both non-profit (7.0 per cent) and for-profit (5.2 per cent) employers.

\section{The adoption of market-based practices}

Market-inspired instruments have been applied differently within care for older people in the Nordic region. The variation between the four countries is statistically significant for every single instrument (table 2). According to the data, customer choice and competitive tendering are still experienced by the minority of care workers, while quality-control mechanisms, the separation of needs-assessments, and the presence of for-profit providers affect the majority, that is, over 60 per cent of respondents.

Table 2. The adoption of market-based practices according to Nordic care workers by country $\left(\% ; \chi^{2}\right)$

\begin{tabular}{|c|c|c|c|c|c|c|}
\hline Variables & $\begin{array}{l}\text { All participants } \\
\quad(\mathrm{n}=2716)\end{array}$ & $\begin{array}{c}\text { Denmark } \\
(n=790)\end{array}$ & $\begin{array}{l}\text { Finland } \\
(n=654)\end{array}$ & $\begin{array}{l}\text { Norway } \\
(\mathrm{n}=716)\end{array}$ & $\begin{array}{l}\text { Sweden } \\
(n=556)\end{array}$ & $\chi^{2}$ \\
\hline \multicolumn{7}{|c|}{ Quality control $(n=1499)$} \\
\hline Yes (\%) & 68.3 & 82.5 & 65.7 & 61.2 & 59.9 & $58.3^{* * *}$ \\
\hline \multicolumn{7}{|c|}{$\begin{array}{l}\text { For-profit providers in } \\
\text { municipality }(n=2257)\end{array}$} \\
\hline Yes $(\%)$ & 61.7 & 77.4 & 86.2 & 23.3 & 53.4 & $594.4^{* \star *}$ \\
\hline \multicolumn{7}{|c|}{$\begin{array}{l}\text { Separate needs assessments } \\
(\mathrm{n}=2279)\end{array}$} \\
\hline Yes (\%) & 60.7 & 83.5 & 29.2 & 42.1 & 77.7 & $501.7^{* \star \star}$ \\
\hline \multicolumn{7}{|c|}{ Customer choice $(n=1619)$} \\
\hline Yes (\%) & 36.9 & 69.8 & 30.6 & 12.7 & 13.3 & $418.9^{\star \star \star}$ \\
\hline \multicolumn{7}{|c|}{$\begin{array}{l}\text { Competitive tendering } \\
(\mathrm{n}=1990)\end{array}$} \\
\hline Yes (\%) & 22.5 & 44.4 & 22.2 & 4.9 & 16.6 & $271.4^{* * *}$ \\
\hline
\end{tabular}

Source: NORDCARE data $p<0.05 ; ; p<0.01 ; \quad p<0.001$

Overall, market-based practices seem to be most widespread in Denmark, as it displays in the data the highest proportions of care workers who have experienced quality control (82.5 per cent), separation of needs-assessments (83.5 per cent), customer choice (69.8 per cent) as well as competitive 
tendering (44.4 per cent) in their workplaces. Finland has the highest prevalence of for-profit providers (86.2 per cent), while in Sweden the separation of needs-assessments from provision ( 77.7 per cent) is the most widely applied market-based practice. In Norway the frequency of each of these models remains below the all-Nordic level within the data. However, the number of missing values is exceptionally high for all of these five items. Concerning the existence of quality-control mechanisms and customer choice in the workplace, more than a third of respondents did not answer the question. It seems that for a large proportion of care workers, market-based models and their names were so unfamiliar that many had to leave these questions unanswered.

\section{Work satisfaction of care workers}

Has the privatization of care services affected work satisfaction of Nordic social- and health-care staff working with older people? This can be analysed most directly by comparing the responses of publicly employed care workers with those of other care workers. Is there a variation between care staff employed by public, non-profit, for-profit and other employers?

Table 3. Work satisfaction of Nordic care workers working with older people by employer (\%; mean; $\chi^{2}$ )

\begin{tabular}{|c|c|c|c|c|c|c|}
\hline Variables & $\begin{array}{l}\text { All participants } \\
\qquad(\mathrm{n}=2642)\end{array}$ & $\begin{array}{l}\text { Public } \\
\text { employer } \\
(n=2495)\end{array}$ & $\begin{array}{l}\text { Non-profit } \\
\text { employer } \\
(n=61)\end{array}$ & $\begin{array}{l}\text { For-profit } \\
\text { employer } \\
(n=65)\end{array}$ & $\begin{array}{l}\text { Other } \\
\text { employer } \\
(n=21)\end{array}$ & $\chi^{2}$ \\
\hline \multicolumn{7}{|l|}{$\begin{array}{l}\text { Work tasks interesting and } \\
\text { meaningful }(n=2669)\end{array}$} \\
\hline $\begin{array}{l}\text { Most often }(\%) \\
\text { Opportunity to develop } \\
\text { professionally }(n=2675)\end{array}$ & 77.5 & 77.8 & 83.3 & 63.1 & 76.2 & 10.6 \\
\hline $\begin{array}{l}\text { Most often }(\%) \\
\text { Opportunity to affect the daily } \\
\text { planning of work }(n=2673)\end{array}$ & 30.4 & 29.9 & 40.7 & 35.4 & 52.4 & 16.6 \\
\hline $\begin{array}{l}\text { Most often }(\%) \\
\text { Sufficient information on } \\
\text { changes at workplace } \\
(\mathrm{n}=2678)\end{array}$ & 43.8 & 43.7 & 45.9 & 46.2 & 47.6 & 15.3 \\
\hline $\begin{array}{l}\text { Most often (\%) } \\
\text { Enough time to discuss with } \\
\text { colleagues ( } n=2688)\end{array}$ & 44.2 & 43.8 & 53.3 & 53.8 & 38.1 & $19.2^{*}$ \\
\hline $\begin{array}{l}\text { Most often }(\%) \\
\text { Support from closest manager } \\
(n=2670)\end{array}$ & 51.7 & 51.8 & 55.7 & 45.3 & 38.1 & $26.9^{\star *}$ \\
\hline $\begin{array}{l}\text { Most often }(\%) \\
\text { Access to in-service training } \\
(n=2616)\end{array}$ & 44.4 & 44.4 & 45.9 & 46.9 & 28.6 & 9.2 \\
\hline Most often (\%) & 24.1 & 24.4 & 23.0 & 18.3 & 15.0 & 7.1 \\
\hline $\begin{array}{l}\text { Work-satisfaction summary } \\
\text { index }^{a} \quad(n=2507) \text { (mean) }\end{array}$ & 22.7 & 22.7 & 23.1 & 21.8 & 21.6 & $88.4^{\star \star}$ \\
\hline
\end{tabular}


The short answer to these questions is both yes and no. Concerning two items of work satisfaction, whether care workers receive sufficient information on changes in the workplace and whether there is enough time to discuss work problems with colleagues, there is statistically significant variation (table 3 ). However, the results are contradictory because care workers employed by forprofit organizations are less satisfied with their opportunities for collegial discussion compared with publicly employed staff, whereas they are the most satisfied employee group when it is the availability of information on workplace changes that is in question. Concerning the other five items of work satisfaction included in the analysis, there are no statistically significant variations between different kinds of employers. The number of cases in all non-publicly employed care-worker groups remained rather low, which weakens the analysis and its statistical significance.

Nevertheless, when a summary index of work satisfaction is constructed, ${ }^{4}$ statistically significant variation reappears. The highest average summary score of work satisfaction (23.1) is found among care workers employed by non-profit organizations, followed by public employees (22.7). Correspondingly, care workers employed by for-profit and other employers have on average the lowest total values of the work satisfaction summary index (21.8 and 21.6).

\section{Connections between the adoption of market-based models and work satisfaction}

Pearson's correlations are used here to analyse the connections between work satisfaction and the adoption of different market-based practices within care services for older people. If these practices are detrimental to work satisfaction, those care workers who have experienced the adoption of these models in their workplace would be expected to have lower values for the summary index.

Correlation values are counted for the whole sample but also country by country so that it is possible to compare the results both between the four Nordic countries and between different market-based instruments. Three of the five instruments studied receive statistically significant correlations with work satisfaction within the whole sample. These are the introduction of quality control mechanisms $\left(.214^{* *}\right)$, customer choice $\left(.095^{\star *}\right)$, and the presence of for-profit providers $\left(.060^{\star *}\right)$. What is remarkable is that each of these three correlations are positive, which means that the adoption of these marketbased practices is connected with higher and not lower levels of work satisfaction. The only market-inspired model that receives a negative correlation with the work-satisfaction summary index within the all-Nordic sample is the separation of needs-assessments from service provision, but this correlation is not statistically significant.

\footnotetext{
${ }^{4}$ The summary index displays a very satisfactory level of reliability (Cronbach $\alpha=$ 0.763). Out of the original ten work-satisfaction items of the questionnaire, three items (b, i, and j) were left out of the summary index - and out of table 2, as well - as they would have slightly weakened the reliability of the summary index.
} 
Table 4. Correlations $s^{\mathrm{a}}$ between the adoption of market-based practices ${ }^{\mathrm{b}}$ and work satisfaction ${ }^{c}$ of Nordic care workers working with older people by country

\begin{tabular}{|c|c|c|c|c|c|c|}
\hline Variables & & $\begin{array}{c}\text { Denmark } \\
(n=741)\end{array}$ & $\begin{array}{l}\text { Finland } \\
(n=618)\end{array}$ & $\begin{array}{l}\text { Norway } \\
(n=626)\end{array}$ & $\begin{array}{l}\text { Sweden } \\
(n=522)\end{array}$ & $\begin{array}{c}\text { All } \\
\text { participants } \\
(\mathrm{n}=2507) \\
\end{array}$ \\
\hline $\begin{array}{l}\text { Quality control } \\
(n=1499)\end{array}$ & $r$ & .092 & $.158^{* *}$ & $.343^{* *}$ & $.167^{*}$ & $.214^{* *}$ \\
\hline $\begin{array}{l}\text { For-profit } \\
\text { providers in } \\
\text { municipality } \\
(n=2257)\end{array}$ & $r$ & .003 & .073 & -.038 & -.001 & $.060^{* *}$ \\
\hline $\begin{array}{l}\text { Separate } \\
\text { needs } \\
\text { assessments } \\
(n=2279)\end{array}$ & $r$ & -.066 & .012 & -.030 & -.023 & -.037 \\
\hline $\begin{array}{l}\text { Customer } \\
\text { choice } \\
(n=1619)\end{array}$ & $r$ & .064 & $.116^{*}$ & .062 & -.092 & $.095^{\star *}$ \\
\hline $\begin{array}{l}\text { Competitive } \\
\text { tendering } \\
(n=1990)\end{array}$ & $r$ & -.063 & .071 & -.021 & .033 & .028 \\
\hline
\end{tabular}

Source: NORDCARE data

a Pearson correlation value

${ }^{\mathrm{b}} 0=$ no; 1 = yes; 'does not know' marked as missing value

${ }^{c}$ Summary index ranging from $7=$ fully unsatisfied to $28=$ fully satisfied

$p<0.05{ }^{*} p<0.01$ (2-tailed significance test)

Within national samples, there are four statistically significant correlations between work satisfaction of care workers and the presence of market-based practices. Each of the four correlations is positive, and three of them concern the adoption of quality-assurance mechanisms: in Norway $\left(.343^{* *}\right)$, Finland $\left(.158^{* *}\right)$, and Sweden $\left(.167^{*}\right)$ the quality control of care services is correlated with higher levels of work satisfaction. Also the presence of customer choice has a positive correlation of statistical significance with the work-satisfaction summary index in the sample from Finland $\left(.116^{*}\right)$. There are also negative correlations between work satisfaction and the adoption of market-based practices in national samples (for example, concerning customer choice in Sweden: -.092), but none of these have statistical significance.

\section{Discussion}

The aim of this article has been to address the question of whether the recent adoption of market-based practices within Nordic care services for older people constitutes a risk for the work satisfaction of care workers. Earlier research discussion on the changing character of Nordic care service systems, juxtaposing the rationality of caring with the rationality of efficiency inherent in the NPM approach, suggests the existence of such a risk. As a way to find answers to this research question, the article has analysed comparative Nordic questionnaire data looking at whether there are 
differences in the level of self-reported work satisfaction between those care workers who have experienced the adoption of privatization and NPM-inspired managerialism in their workplaces and those care workers who have not yet had such experiences. The question of whether the adoption of market-based practices is connected with the level of work satisfaction has been analysed here through comparisons between four Nordic countries as well as between different market-based models.

The results show, first of all, that there are significant variations concerning the spread of market-based practices between Denmark, Finland, Norway, and Sweden. According to the data, for-profit providers are most usual in Finland, but all other studied market-based practices are most widespread in Denmark. On an all-Nordic level, quality-control systems, the presence of for-profit providers, and the separation of needs assessments are already an experience of the majority, while customer choice and competitive tendering have gained ground at a slower pace. Unfortunately, many respondents seem to have been unfamiliar with the terms of market-based practices and did not answer the questions on their existence. The high number of missing values weakens the significance of the findings.

Concerning the level of work satisfaction, measured with the work-satisfaction summary index that was constructed from seven original items, it was found to be highest among care workers who are employed by public and non-profit organizations, and lowest among the employees of for-profit (and other) organizations. This finding suggests that increasing privatization of Nordic care services for older people might be connected to deteriorating levels of work satisfaction of care workers. However, here the low number of respondents employed by non-public organizations made a developed analysis impossible. It is clear that more research is required to gain a firm understanding on this issue.

For their part, the results from the correlation analysis do not support the argument that market-based practices jeopardize the work satisfaction of Nordic care workers. Only the separation of needs-assessments from service provision was correlated with a weaker level of work satisfaction in the whole sample, and this correlation did not have statistical significance. On the other hand, the positive correlations between work satisfaction and quality-control mechanisms, customer choice, and the existence of local for-profit service providers were statistically significant. The strongest connection was found between the introduction of quality-control systems and work satisfaction: quality control was correlated with higher levels of work satisfaction in a statistically significant way, not only on the all-Nordic level but also within the national samples from Finland, Norway, and Sweden.

The results are partly contradictory. The comparison between different kinds of employers suggests that privatization might bring problems for work satisfaction, but the correlation analysis shows instead that the adoption of most NPM-inspired models is connected to higher and not lower levels of work satisfaction. This discrepancy in the findings of the study is a cause for caution when making final conclusions and policy recommendations.

Caution is warranted for other reasons as well. The analysis showed large variations, on the one hand, between different market-based models and, on the other hand, between the four Nordic countries. Market-based practices might not in the end form a coherent package that brings only either positive or negative implications. One model may be associated with strong work satisfaction and another model with weak work satisfaction. Furthermore, in 
the data, individual market-inspired models could be connected with a higher level of work satisfaction in one country and with a lower level in another country. It is thus not only the model in itself but also the national context that is decisive. The four Nordic countries are clearly at different stages in adopting the new models, the extremes being Denmark, where all the studied marketbased practices are already widely applied, and Norway, where most of these models are still experienced only by a minority of care workers working with older people. The national context structures the interaction between marketbased models and work satisfaction, and results from the all-Nordic level cannot be used as a simple guideline for policy-making at the national level.

Finally, caution in making firm conclusions and policy recommendations is also needed because of some weaknesses of the data. The Nordic team that gathered the data aimed for the best possible comparability between countries, but having the questionnaire translated into four different languages in itself weakens the comparability. The terms used have different meanings in different languages, which cannot be avoided. The four Nordic countries are not identical: their cultures, occupational structures, and care service systems have their national characteristics and all these make full comparability of responses difficult to achieve. Furthermore, within the data there were only a few care workers who were employed by non-public employers, and the number of missing values in questions on the workplace presence of the market-based models was high. These weaknesses of the data call for extra caution in the interpretation of the findings.

All in all, it is not possible to make general policy recommendations for or against the adoption of market-based instruments on the basis of the results of this study. It is necessary for policymakers to remain sensitive to the national context, as this seems to have vital importance. It also seems that marketbased instruments should not be perceived as one single package since the connections between individual instruments and work satisfaction of care workers are non-identical. Finally, it is necessary to remember that the work satisfaction of care workers is only one among numerous different indicators that could be used to evaluate the adoption of market-based models in Nordic care policies. Work strain, work-family balance, remuneration levels, and many other criteria could be used to analyse whether the adoption of marketbased models represents a change for good or for bad for care workers. Moreover, care workers are certainly not the only group that is affected by changing care systems. In order to obtain a full picture, researchers should not forget to examine the implications of policy switches for care users and their family members.

\section{References}

Anttonen, A. (1990). The feminization of the Scandinavian welfare state. In L. Simonen (Ed.), Finnish Debates on Women's Studies: Women's Worlds, Realities and Choices. Tampere: University of Tampere.

Behning, U. (2005). Changing long-term care regimes: a six-country comparison of directions and effects. In B. Pfau-Effinger, \& B. Geissler (Eds.), Care and Social Integration in European Societies (pp. 73-91). Bristol: Policy Press.

Dahl, H. M. (2005). A changing ideal of care in Denmark: A different form of retrenchement? In H. M. Dahl \& T. R. Eriksen (Eds.), Dilemmas of Care in the Nordic Welfare State (pp. 47-61). Aldershot: Ashgate. 
Doyle, M., \& Timonen, V. (2007). Home Care for Ageing Populations: A Comparative Analysis of Domiciliary Care in Denmark, the United States and Germany. Cheltenham: Edward Elgar.

Edebalk, P. G., \& Svensson, M. (2005). Kundval för äldre och funktionshindrade $i$ Norden. Konsumentperspektivet [Customer choice for older and disabled people in the Nordic countries: the consumer perspective]. Copenhagen: Nordic Council of Ministers.

Hannan, S., Norman , I. J. \& Redfern, S. J. (2001). Care work and quality of care for older people: A review of the research literature. Reviews in Clinical Gerontology, 11(2), 189-203.

Hasselbladh, H., Bejerot, E., \& Gustafsson, R. A. (2008). Bortom New Public Management - Institutionell transformation i svensk sjukvård [Beyond New Public Management: Institutional transformation in Swedish health care]. Lund: Academia Adacta.

Häggström, E., Skovdahl, K., Fläckman, B., Kihlgren, A. L. \& Kihlgren, M. (2005). Work satisfaction and dissatisfaction: caregivers' experiences after a two-year intervention in a newly opened nursing home. Journal of Clinical Nursing, 14(1), 9-19.

Højlund, H. (2001). Kvalitetsudvikling og velfærdsparadokser [Quality development and welfare paradoxes]. In AEldreomsorg - management eller menneskelighed? [Care for older people: management or humaneness?] (pp. 79-96). Hellerup: Videnscenter på ÆEldreområdet.

Julkunen, R. (2004). Hyvinvointipalvelujen uusi politiikka [The new politics of welfare services]. In L. Henriksson, \& S. Wrede (Eds.), Hyvinvointityön ammatit [Professions of welfare work] (pp. 168-186). Helsinki: Gaudeamus.

Karlsson, M., Iversen, T. \& Øien, H. (2010). Scandinavian Long-Term Care Financing. Oslo: University of Oslo.

Koskiaho, B. (2008). Hyvinvointipalvelujen tavaratalossa. Palvelutalous ja sosiaalipolitiikka Englannissa, Ruotsissa ja Suomessa [In the supermarket of welfare services: Service economy and social policy in England, Sweden and Finland]. Tampere: Vastapaino.

Kröger, T., Leinonen, A., \& Vuorensyrjä M. (2009). Hoivan tekijät. Suomalainen hoivatyö pohjoismaisessa tarkastelussa [Makers of care: Finnish care work in the Nordic context], Jyväskylä: University of Jyväskylä,

Kröger, T. (2009). Hoivapolitiikan rajanvetoja [Boundaries in care policy]. In A. Anttonen \& H. Valokivi \& M. Zechner (Eds). Hoiva. Tutkimus, politiikka ja arki [Care: research, politics, and everyday life] (99-125). Tampere: Vastapaino.

Kröger, T. (2011). Retuning the Nordic welfare municipality: central regulation of social care under change in Finland, International Journal of Sociology and Social Policy, 31(3), 148 - 159

Locke, E. A. (1976). The nature and causes of job satisfaction. In M. D. Dunnette \& L. M. Hough (Eds.), Handbook of Industrial and Organizational Psychology (pp. 1319-1328). Palo Alto, CA: Consulting Psychologists Press.

Lund Pedersen, L. (1998). Health and social care for older people in Denmark: a public solution under threat? In C. Glendinning (Ed.), Rights and Realities: Comparing New Developments in Long-term Care for Older People (pp. 83-103). Bristol: Policy Press. 
Martimo, K. (1998). Community care for frail older people in Finland. In C. Glendinning (Ed.), Rights and Realities: Comparing New Developments in Long-term Care for Older People (pp. 67-81). Bristol: Policy Press.

Means, R., Morbey, H., \& Smith, R. (2002). From Community Care to Market Care? The Development of Welfare Services for Older People. Bristol: Policy Press.

Redfern, S., Hannan, S., Norman, I. \& Finbarr, M. (2002). Work satisfaction, stress, quality of care and morale of older people in a nursing home. Health and Social Care in the Community, 10(6), 512-517.

Rode, J. C. (2004). Job satisfaction and life satisfaction revisited: aA longitudinal test of an integrated model. Human Relations 57(9), 1205-1230.

Sipilä, J. (Ed.) (1997). Social Care Services: The Key to the Scandinavian Welfare Model. Aldershot: Avebury.

Szebehely, M. (2001). Kvalitetssikring - en trussel mod hjemmeplejens omsorgsidealer? [Quality assurance: a threat to care ideals of home-based care?]. In AEldreomsorg - management eller menneskelighed? [Care for older people: management or humaneness?] (pp. 117-125). Hellerup: Videnscenter på ÆEldreområdet.

Söderström, L. (2001). Privatiseringens gränser: perspektiv på välfärdspolitiken [Limits of privatisation: perpectives on welfare policy]. Stockholm: SNS Förlag.

Trydegård, G.-B. (2005). Äldreomsorgspersonalens arbetsvillkor i Norden - en forskningsöversikt [Working conditions for staff in care for older people in the Nordic countries: A review of research]. In M. Szebehely (Ed.) Äldreomsorgsforskning i Norden. En kunskapsöversikt [Research on care for older people in the Nordic countries: A review of the state of the art] (pp. 143195). Köpenhamn: Nordiska Ministerrådet.

Vabø, M. (2003). Mellan traditioner och trender [Between traditions and trends]. In M. Szebehely (Ed.), Hemhjälp i Norden: illustrationer och reflektioner [Home care in the Nordic countries: illustrations and reflections] (pp. 63-87). Lund: Studentlitteratur.

Weiss, H. M. (2002). Deconstructing job satisfaction: separating evaluations, beliefs and affective experiences. Human Resource Management Review, 12(2), 173194

Wistow, G., Knapp, M., Hardy, B., \& Allen, C. (1994). Social Care in a Mixed Economy. Buckingham: Open University Press.

Wistow, G., Knapp, M., Hardy, B., Forder, J., Kendall, J., \& Manning, R. (1996) Social Care Markets: Progress and Prospects. Buckingham: Open University Press. 